\title{
Abdominal aortic pseudocoarctation associated with renal artery occlusion
}

\author{
Yalcin Solak, ${ }^{1}$ Zeynep Biyik, ${ }^{1}$ Orhan Ozbek, ${ }^{2}$ Abduzhappar Gaipov ${ }^{1}$
}

${ }^{1}$ Department of Nephrology, Konya University Meram School of Medicine, Konya, Turkey ${ }^{2}$ Deaprtment of Radiology, Konya University Meram School of Medicine, Konya, Turkey

\section{Correspondence to}

Dr Abduzhappar Gaipov abduzhappar@gmail.com
To cite: Solak Y, Biyik $Z$, Ozbek 0, et al. BMJ Case Reports Published online: [please include Day Month Year] doi:10.1136/bcr-2012007442

\section{DESCRIPTION}

A 45 -year-old man was admitted to hospital due to uncontrolled hypertension. He had hypertension for 15 years and was on trandolapril+verapamil and cardura treatment. One year ago renal artery stenosis was detected by ultrasound but the patient declined further evaluation at that time. He had no symptomatic coronary artery disease or peripheral arterial disease. He denied chest pain, intermittent claudication and syncope. At admission blood pressure was $200 / 110 \mathrm{~mm} \mathrm{Hg}$ and there was no difference at both arms. There was no pulse delay in the lower extremities. Pulse examination was normal. There were no murmurs at cardiac auscultation. No carotid bruit was heard. There was a severe abdominal bruit over the trajectory of the left renal artery. Serum creatinine was $1.1 \mathrm{mg} / \mathrm{dl}$ and potassium was $4.6 \mathrm{mEq} / \mathrm{l}$. There was normal urinalysis. Renal Doppler ultrasound showed the following findings: right kidney $104 \times 44 \mathrm{~mm}$, left kidney $116 \times 45 \mathrm{~mm}$, cortical thickness was normal and echogenity was grade 1 increased. Contrast-enhanced abdominal CT angiography (figure 1A) revealed a left kidney of $97 \mathrm{~mm}$ longitudinal length. There was severe tortuosity in the distal parts of the aorta along with an aortic pseudocoarctation. The origin of the left renal artery from the aorta was not sufficiently visualised. Nephrogram was delayed in the left kidney. The patient underwent conventional angiography (figure 1B). Left main renal artery and renal parenchyma were not enhanced with contrast. The angiographic picture was consistent with renal artery occlusion. Stent placement could not be carried out due to near total occlusion of the vessel. The patient declined surgical revascularisation. His blood pressure control was attained with ramipril, doxazosin, spirinolactone, amlodipin and metoprolol.

Abdominal aortic pseudocoarctation (AAP) is exceedingly rare. Previously, we had reported abdominal aortic pseudocoarctation incidentally found in a patient who was being searched for a secondary hypertension cause. ${ }^{1}$ To our knowledge, this is the sixth reported case of AAP in the literature. The thoracic form of the condition that is much more prevalent usually involves the aortic arch and may be associated with pseudoaneurysm formations. ${ }^{2}$ AAP is generally recognised as a benign condition with no luminal narrowing and consequent significant clinical associations. ${ }^{3}$ In only one of the previously reported cases, AAP was associated with bilateral atherosclerotic renal artery stenosis. ${ }^{4}$ In our patient, AAP was associated with left renal artery occlusion. This may represent only an incidental co-occurrence. On the other hand, severe atherosclerotic disease may have distorted both abdominal aorta and the renal arteries.

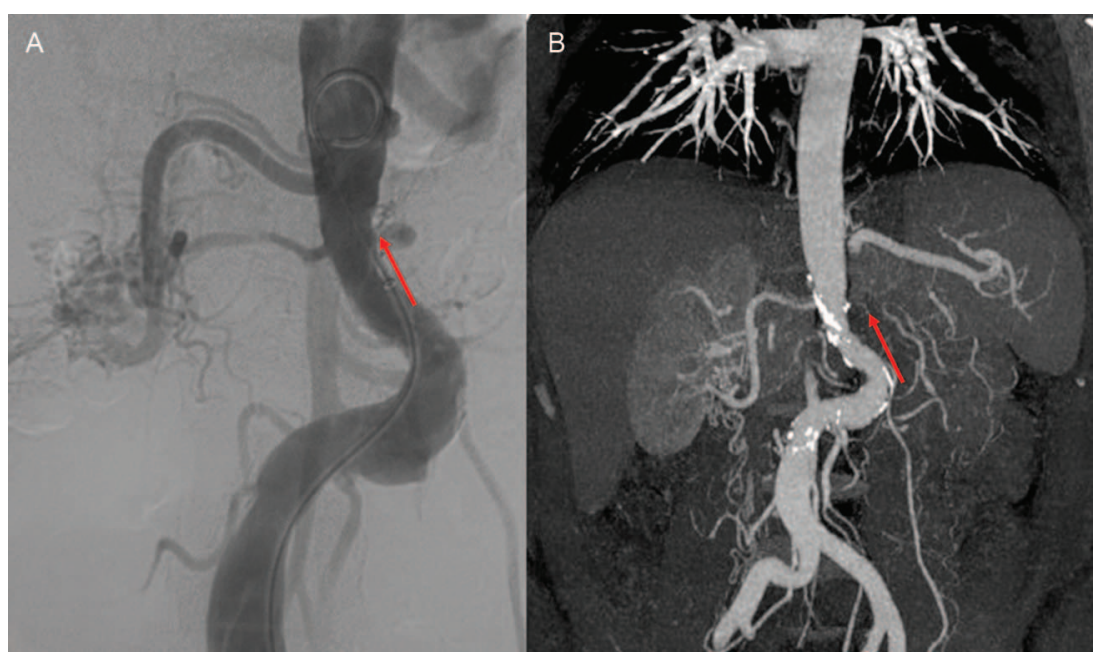

Figure 1 Digital subtraction angiography $(A)$ and contrast-enhanced coronal reformatted MIP (maximum intensity projection) images on multidetector computed tomography (MDCT) of the abdomen (B) showing severe abdominal aortic pseudocoarctation and absence of left renal perfusion due to renal artery occlusion (arrows). There are calcific atherosclerotic plaques in the MDCT section. 


\section{Learning points}

- Abdominal aortic pseudocoarctation is a very rare developmental abnormality and may be a potential renovascular cause of uncontrolled secondary hypertension.

- Contrast-enhanced abdominal CT angiography or conventional abdominal aortography can establish the final diagnosis.

- Abdominal aortic stenting or surgical angioplasty is the only effective treatment for abdominal aortic pseudocoarctation and renal artery stenosis.

Acknowledgements We thank Assistant Professor Dr Osman Koc and Professor Dr Halil Zeki Tonbul for their contribution in the treatment and management of the patient's care, and approval of the version to be published.
Competing interests None.

Patient consent Obtained.

Provenance and peer review Not commissioned; externally peer reviewed.

\section{REFERENCES}

1 Solak Y, Atalay $\mathrm{H}$, Turkmen $\mathrm{K}$, et al. An incidental finding while investigating secondary hypertension: severe abdominal aortic pseudocoarctation. NDT Plus 2009;2:328.

2 Choi BW, Choe KO, Kim YJ. Magnetic resonance angiography of pseudocoarctation. Heart 2004;90:1213.

3 Etemad-Rezai R, Rankin RN. Abdominal aortic pseudocoarctation. CMAJ 2009:180:317-18.

4 Kawarabayashi T, Nishikimi T, Takeuchi K, et al. Pseudo-coarctation of the abdominal aorta associated with renovascular hypertension. Angiology 1985;36:215-18.

Copyright 2013 BMJ Publishing Group. All rights reserved. For permission to reuse any of this content visit http://group.bmj.com/group/rights-licensing/permissions.

BMJ Case Report Fellows may re-use this article for personal use and teaching without any further permission.

Become a Fellow of BMJ Case Reports today and you can:

- Submit as many cases as you like

- Enjoy fast sympathetic peer review and rapid publication of accepted articles

- Access all the published articles

- Re-use any of the published material for personal use and teaching without further permission

For information on Institutional Fellowships contact consortiasales@bmjgroup.com

Visit casereports.bmj.com for more articles like this and to become a Fellow 